\title{
CYR61 suppresses growth of human malignant melanoma
}

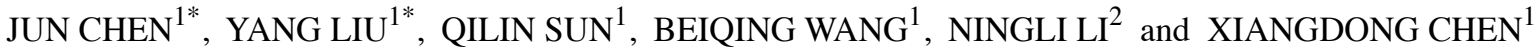 \\ ${ }^{1}$ Department of Dermatology and Dermatologic Surgery, Shanghai Ninth People's Hospital \\ Affiliated to Shanghai Jiaotong University School of Medicine; ${ }^{2}$ Department of Immunology, \\ Shanghai Jiaotong University School of Medicine, Shanghai 200011, P.R. China
}

Received March 10, 2016; Accepted July 18, 2016

DOI: 10.3892/or.2016.5124

\begin{abstract}
Cysteine-rich protein 61 (CCN1/CYR61) is an important marker of proliferation and metastasis in malignant melanoma, making it a potential target for melanoma treatment. In this study, we compared the expression of CRY61 in Chinese patients with malignant melanoma with its expression in patients with other skin tumors or with no skin pathological conditions. We examined the effects of anti-human CYR61 monoclonal antibody on proliferation and evaluated the changes in CYR61 expression and cell proliferation in response to treatment with either epirubicin or interferon (IFN)- $\alpha$. CYR61 was expressed at lower levels in patients with malignant melanoma than in patients with other skin tumors or with no pathology. Following the treatment of B16 cells with epirubicin and IFN- $\alpha$, CYR61 levels increased, cell growth was inhibited, and proliferating cell nuclear antigen expression decreased. Thus, CYR61 could become a therapeutic target for malignant melanoma patients with high CYR61 expression.
\end{abstract}

\section{Introduction}

Cysteine-rich protein 61 (CYR61) encodes a protein with $10 \%$ cysteine residues and was first described in 1985 , as an immediate early gene, which can be induced by serum or platelet-derived growth factor (PDGF) (1). CYR61 is a secreted, extracellular matrix (ECM)-associated signaling molecule that belongs to the $\mathrm{CCN}$-gene family.

Correspondence to: Dr Ningli Li, Department of Immunology, Shanghai Jiaotong University School of Medicine, Shanghai 200011, P.R. China

E-mail: ninglixiaoxue57@163.com

Dr Xiangdong Chen, Department of Dermatology and Dermatologic Surgery, Shanghai Ninth People's Hospital Affiliated to Shanghai Jiaotong University School of Medicine, 639 Zhizaoju Road, Shanghai 200011, P.R. China

E-mail: xdchen@medmail.com.cn

${ }^{*}$ Contributed equally

Key words: cysteine-rich protein 61, malignant melanoma, proliferation, epirubicin, interferon- $\alpha$, Chinese population
The CCN family includes six distinct genes: CYR61/CCN1, connective tissue growth factor (CTGF)/CCN2, nephroblastoma overexpressed gene (NOV)/CCN3, and Wnt-induced secreted proteins WISP-1/CCN4, WISP-2/CCN5, and WISP-3/CCN6 (2). These are matri-cellular regulatory factors involved in internal and external cell signaling. They play a role in angiogenesis, chondrogenesis, and osteogenesis, by stimulating mitosis, adhesion, apoptosis, ECM production, and growth arrest and migration of multiple cell types (3).

Human CYR61 maps to p22.3 on chromosome 1, encodes a 384-residue protein, and yields a 360-residue protein containing 38 conserved cysteine residues after signal peptide cleavage (4-7). To date, a number of studies describe the involvement of CYR61 in many cell functions, such as cell adhesion, migration, proliferation, apoptosis and angiogenesis (8-10).

As integrin receptor, CYR61 is expressed in various tissues and may have different physiological functions (11-14). However, expression profiles of CYR61 in malignant melanoma have been inconsistent. Babic et al and Kunz et al reported CYR61 overexpression in malignant melanoma, possibly related to cell migration $(15,16)$. However, in 2009, Dobroff et al demonstrated that silencing the cAMP-response element-binding protein (CREB) in two human metastatic melanoma cell lines, A375SM and C8161-c9, resulted in suppressed tumor growth and metastasis and increased CYR61 expression (17). They pointed to the possibility of inducing expression of CYR61 as potential therapeutic method for malignant melanoma. To date, the expression profile of CYR61 in Chinese patients with malignant melanoma has not been studied.

Here, we determined the levels of CYR61 in samples obtained from Chinese patients with malignant melanoma or other skin tumors, and compared them with those of patients with no skin pathology. Among these malignant tumors, we analyzed CYR61 expression in samples derived from different clinical stages using anti-CYR61 monoclonal antibody (mAb). Our results showed that CYR61 was expressed at low levels in malignant melanoma, which is consistent with previous studies (17). Furthermore, we examined the role of CYR61 on the growth of B16 cell line. We also explored CYR61 expression in B16 cells, when exposed to either epirubicin or interferon (IFN)- $\alpha$. The results showed that epirubicin and IFN- $\alpha$ inhibited B16 proliferation and subsequently significantly decreased CYR61 expression. Moreover, the increased apoptosis in 
B16 cells was consistent with the reduced expression of proliferating cell nuclear antigen (PCNA). Taken together, we provide evidence that epirubicin and IFN- $\alpha$ negatively impacted B16 cell proliferation and reduced their expression of CYR61 and PCNA, thus indicating CYR61 as a potential target for malignant melanoma treatment.

\section{Materials and methods}

Reagents. Monoclonal anti-CYR61 antibodies were obtained from Sigma-Aldrich (St. Louis, MO, USA). EliVision ${ }^{\mathrm{TM}}$ plus Polyer HRP (mouse/rabbit) immunohistochemistry (IHC) kit was provided by Fuzhou Maxin Biotechnology Co., Ltd. (Fuzhou, China). ${ }^{3} \mathrm{H}-\mathrm{TdR}$ was a gift from the Shanghai Institute of Applied Physics, Chinese Academy of Sciences (Shanghai, China). SYBR ${ }^{\circledR}$ Green PCR Master Mix was purchased from Applied Biosystems (Foster City, CA, USA) and TRIzol was obtained from Invitrogen (Carlsbad, CA, USA). Cyr61 protein was supplied by Peprotech, Inc. (Rocky Hill, NJ, USA).

Tissue microarray (TMA) and IHC assay. The TMA containing malignant melanoma, other skin tumors, and normal skin, was obtained from Xi'an Alena Biotechnology Ltd., Co. (Xi'an, China). IHC studies were performed using the standard EliVision ${ }^{\mathrm{TM}}$ method. In brief, TMA sections were deparaffinized, rehydrated, and endogenous peroxidase activity was blocked by treatment with $3 \%$ hydrogen peroxide for $20 \mathrm{~min}$. For antigen retrieval, TMA slides were microwave-treated in $10 \mathrm{mM}$ citrate buffer $(\mathrm{pH} \mathrm{6.0)}$ ) for $10 \mathrm{~min}$. The slides were incubated with mouse $\mathrm{mAb}$ against human CYR61 (1:100 dilution), overnight at $4^{\circ} \mathrm{C}$, followed by incubation with an HRP-conjugated goat anti-mouse polyclonal antibody for $60 \mathrm{~min}$, and subsequent reaction with 3,3'-diaminobenzidine (DAB). The nuclei were counterstained with hematoxylin. Negative controls were performed by replacing the primary antibody with mouse IgG. To evaluate the IHC staining of CYR61 in malignant melanoma, other skin tumors, and normal skin, a semi-quantitative scoring criteria for IHC of CYR61 was used, in which both staining intensity and positive areas were recorded as - (negative), + (weak positive), ++ (moderate positive), and +++ (strong positive).

Cell lines and culture conditions. B16, a mouse melanoma cell line derived from spontaneous skin tumors in C57BL/6 mouse, was obtained from Shanghai Institutes for Biological Sciences, CAS, Shanghai, China. B16 melanoma cells were maintained in Dulbecco's modified Eagle's medium (DMEM; HyClone, Logan, UT, USA) supplemented with $20 \%$ fetal calf serum (FCS), penicillin $100 \mathrm{U} / \mathrm{ml}$, streptomycin $100 \mu \mathrm{g} / \mathrm{ml}$ (Gibco, North Andover, MA, USA), L-glutamine 2 mM, 4-(2-hydroxyethyl)piperazine-1-ethanesulfonic acid (HEPES) $10 \mathrm{mM}$, and nonessential amino acids (HyClone). Cells were grown at $37^{\circ} \mathrm{C}$ in a humidified atmosphere containing $5 \% \mathrm{CO}_{2}$ and were routinely passaged every 3-4 days. For passaging cells, parental cells and CYR61-treated cells were released from plastic culture dishes with a trypsin $(0.25 \%)$-EDTA $(1 \mathrm{mM})$ solution (Gibco) for $5 \mathrm{~min}$.

B16 cells at a concentration of $1.48 \times 10^{6}$ were plated and grown in $10-\mathrm{cm}$ Petri dishes with $8 \mathrm{ml}$ of complete culture medium. For the ${ }^{3} \mathrm{H}-\mathrm{TdR}$ method, B16 cells were plated at a concentration of $2.0 \times 10^{3}$ cells/well in complete culture medium, in 96-well flat bottomed culture plates.

Cell proliferation assay. To evaluate the effects of epirubicin $(0,0.075,0.15,0.3,0.6$ and $1.2 \mu \mathrm{g} / \mathrm{ml})$ and IFN- $\alpha\left(0,10^{2}, 10^{3}\right.$, and $10^{4} \mathrm{IU} / \mathrm{ml}$ ) on cell growth, several 96-well plates were plated with $2.0 \times 10^{3}$ cells/well. After $24 \mathrm{~h}$, cells were incubated with drugs at the above mentioned concentrations, measuring any inhibition in cell growth at 12, 24 and $48 \mathrm{~h}$, by using the MTT test.

The methods of Carmichael et al (18) and Alley et al (19) were adapted to our culture conditions. Briefly, the cultures were incubated with $20 \mu 1$ MTT ( $5 \mathrm{mg} / \mathrm{ml}$ in fresh medium) for $4 \mathrm{~h}\left(37^{\circ} \mathrm{C}\right.$ and $\left.5 \% \mathrm{CO}_{2}\right)$. After a 10 min centrifugation to remove the medium and the non-metabolized MTT, $150 \mu \mathrm{l}$ of dimethyl sulfoxide (DMSO; Fluka, Milwaukee, WI, USA) were added to each well to solubilize the MTT formazan produced by the cells. After shaking for $10 \mathrm{~min}$ at room temperature, the amount of colored formazan metabolite was determined by absorbance at $490 \mathrm{~nm}$.

${ }^{3} \mathrm{H}$-TdR incorporation in vitro. B16 cells $\left(1 \times 10^{4} / \mathrm{ml}\right)$ were seeded in 96-well plates (200 $\mu 1 /$ well) and recombinant human CYR61 protein (Peprotech, Inc.) was added at concentrations of $0,0.625,1.25,2.5,5.0$ and $20 \mathrm{ng} / \mathrm{ml}$ for $4 \mathrm{~h}$. Six wells were set for each treatment. Next, the cells were treated with $1 \mu \mathrm{Ci}$ ${ }^{3} \mathrm{H}$ and cultured for another $8 \mathrm{~h}$. They were then washed three times with PBS and digested with $0.125 \%$ trypsin (HyClone). A cell suspension was prepared and leached onto a membrane. This was washed with $10 \%$ trichloroacetic acid, followed by addition of $0.1 \mathrm{~mol} / 1 \mathrm{NaOH}$. Subsequently, anhydrous ethanol was added for decolorization and dehydration. The membrane was dried at $70^{\circ} \mathrm{C}$ and placed in scintillation solution for $24 \mathrm{~h}$ in the dark. Counts per minute were measured using a Trilux 1450 MicroBeta machine (Perkin-Elmer Wallac Inc., USA).

Cell cycle analysis by FACS. B16 cells were incubated in 50-ml culture flasks in DMEM with or without recombinant human CYR61 protein. After $72 \mathrm{~h}$, cells $\left(1 \times 10^{5} / \mathrm{ml}\right)$ were collected, washed repeatedly with PBS containing $0.1 \%$ BSA, centrifuged at 1,000 rpm/min for $10 \mathrm{~min}$, and fixed with Cy5-CD4, Cy5-CD8 antibodies at $4^{\circ} \mathrm{C}$ for $20 \mathrm{~min}$, respectively. Cells were then washed three times with Annexin $\mathrm{V}^{+} / \mathrm{PI}^{-}$buffer. Five microliters of Annexin $\mathrm{V}^{+}$and $5 \mu 1 \mathrm{PI}^{-}$(R\&D Systems, Minneapolis, MN, USA) were added to the culture for another $15 \mathrm{~min}$. The cell cycle distribution was analyzed using a FACScan flow cytometer (BD FACSCalibur; BD Biosciences, San Jose, CA, USA).

Quantitative real-time reverse transcriptase-polymerase chain reaction ( $R T-q P C R)$ analysis. Real-time PCR was performed as previously reported (20). The sequence of primers were as follows: GADPH forward, 5'-GTG AAG GTC GGA GTC AAC G-3' and reverse, 5'-TGA GGT CAA TGA AGG GGT C-3'; $\beta$-actin forward, 5'-TGT CCA CCT TCC AGC AGA TGT-3' and reverse, 5'-AGC TCA GTA ACA GTC CGC CTA G-3'; CYR61 forward, 5'-TCC AGC CCA ACT GTA AAC ATC A-3' and reverse, 5'-GGA CAC AGA GGA ATG CAG CC-3'; PCNA forward, 5'-CCA ATT GTG CCG 
Table I. Expression of CYR61 in 78 tissues of Chinese origin.

\begin{tabular}{|c|c|c|c|c|c|c|c|}
\hline \multirow[b]{2}{*}{ Sample (no.) } & \multirow[b]{2}{*}{ Age (years) } & \multirow[b]{2}{*}{ Clinical stage } & \multicolumn{4}{|c|}{ Staining intensity, n (\%) } & \multirow{2}{*}{$\begin{array}{l}\text { Positive } \\
\text { staining, \% }\end{array}$} \\
\hline & & & - & + & ++ & +++ & \\
\hline \multirow[t]{3}{*}{$\operatorname{SCC}(20)$} & \multirow[t]{3}{*}{$65.8 \pm 16.6$} & $\mathrm{I}$ & $3(37)$ & $5(62)$ & $0(0)$ & $0(0)$ & 62.5 \\
\hline & & II & $7(77)$ & $2(22)$ & $0(0)$ & $0(0)$ & 22.2 \\
\hline & & III & $2(66)$ & $1(3)$ & $0(0)$ & $0(0)$ & 33.3 \\
\hline \multirow[t]{2}{*}{$\mathrm{BCC}(15)$} & \multirow[t]{2}{*}{$65.3 \pm 10.1$} & T1NOM0 & $4(40)$ & $6(60)$ & $0(0)$ & $0(0)$ & 60 \\
\hline & & T2N0M0 & $4(80)$ & $1(20)$ & $0(0)$ & $0(0)$ & 20 \\
\hline \multirow[t]{6}{*}{ MM (15) } & \multirow[t]{6}{*}{$53 \pm 13.6$} & T2NOM0 & $2(100)$ & $0(0)$ & $0(0)$ & $0(0)$ & 0 \\
\hline & & T3N0M0 & $3(100)$ & $0(0)$ & $0(0)$ & $0(0)$ & 0 \\
\hline & & T3N1M0 & $1(100)$ & $0(0)$ & $0(0)$ & $0(0)$ & 0 \\
\hline & & T4NOM0 & $5(71)$ & $2(28)$ & $0(0)$ & $0(0)$ & 28.6 \\
\hline & & T4N1M0 & $1(100)$ & $0(0)$ & $0(0)$ & $0(0)$ & 0 \\
\hline & & $\mathrm{T} 4 \mathrm{~N} 1 \mathrm{M} 1$ & $1(100)$ & $0(0)$ & $0(0)$ & $0(0)$ & 0 \\
\hline Inflammation (8) & $55.1 \pm 10.3$ & - & $2(25)$ & $6(75)$ & $0(0)$ & $0(0)$ & 75 \\
\hline Normal skin (20) & $41.8 \pm 17.4$ & - & $4(20)$ & $16(80)$ & $0(0)$ & $0(0)$ & 80 \\
\hline
\end{tabular}

CYR61, cysteine-rich protein 61; SCC, squamous cell carcinoma; BCC, basal cell carcinoma; MM, malignant melanoma.

AGA AAA GC-3' and reverse, 5'-GAC AGA GCC AGT ATT GGG AGT TG-3'. The above primers were designed and provided by Takara Biotechnology, Co., Ltd. (Dalian, China). cDNA was amplified with SYBR ${ }^{\circledR}$ Green PCR Master Mix (Takara Biotechnology, Co.,Ltd.), by using the 7000 Real-Time PCR system (Applied Biosystems). For target gene quantification, normalization was done based on a Chr.21 assay, C2 . Relative copy numbers ( $\mathrm{RCN}$ ) were determined on the basis of comparative $\Delta \Delta \mathrm{Cq}(\mathrm{Ct})$ method, with a normal control DNA as the calibration standard (21). All experiments were repeated three times. $\mathrm{A}=0.5$-fold-change in $\mathrm{RCN}$ was considered as benchmark for deletion.

Western blot analysis. CYR61 protein in B16 cells was detected by western blot analysis with specific anti-human CYR61 monoclonal antibodies. Following electrophoresis, proteins were transferred to PVDF membrane at $60 \mathrm{~V}$ for $2 \mathrm{~h}$. Membranes were blocked with 5\% non-fat milk, washed with PBS, and incubated with $\mathrm{mAb}$ at $4^{\circ} \mathrm{C}$ overnight. Subsequently, they were incubated with HRP-conjugated goat anti-mouse IgG at room temperature for $45 \mathrm{~min}$, followed by washing with PBS. The target protein was visualized by using autoradiography film (Fujifilm LAS-4000).

Statistical analysis. Group measures were shown as mean \pm SEM. A Student's t-test was used to analyze the differences between each two groups. A one-way ANOVA was initially performed to assess the overall statistical significance, followed by a two-tailed paired or unpaired Student's t-test. A $\mathrm{p}<0.05$ was considered significant.

\section{Results}

Low CYR61 expression in malignant melanoma. Using TMA and IHC, we examined the expression of CYR61 in 78 skin samples from Chinese patients with different clinical diagnoses, stages and pathological types. The expression profile of CYR61 is displayed in Table I. CYR61 levels are low in malignant melanoma (MM) and basal cell carcinoma (BCC) tissues, and high in squamous cell carcinoma $(\mathrm{SCC})$ tissues $(\mathrm{p}<0.01)$, when compared with normal skin tissue. This is different from previous studies where CYR61 was found to be overexpressed in malignant melanoma (17). Next, we examined the correlation between CYR61 levels with the clinical stage and pathological diagnosis. There was no direct relationship between CYR61 expression and the pathological diagnosis or TNM stage in either SCC (Fig. 1A and B) or BCC and MM (Fig. 1C and D). The specificity of the anti-CYR61 antibody was concluded from the positive CYR61 expression detected in tissues exposed to antibody as opposed to the negative one in tissues incubated with control IgG (Fig. 1E).

Recombinant human CYR61 inhibits proliferation and promotes apoptosis in B16 cells. Based on the search results from NCBI HomoloGene, human CYR61 has a high degree of homology to the protein in other species (Fig. 2A). We also found 93\% sequence similarity between CYR61 in human and mouse, confirming reliability of using human CYR61 in B16 cells in vitro (Fig. 2B). B16 cells appeared to grow well under normal conditions (Fig. 2C). However, ${ }^{3} \mathrm{H}-\mathrm{TdR}$ incorporation suggested that human CYR61 suppressed B16 proliferation in vitro, an effect enhanced progressively with increasing concentration of the protein added, up to $5 \mathrm{ng} / \mathrm{ml}$ (Fig. 2D).

Additional to growth suppression, CYR61 protein also had apoptosis promoting effect, proportional with the concentration of the recombinant protein. At $10 \mathrm{ng} / \mathrm{ml}, 30 \%$ of cells were apoptotic, significantly more than when exposed to low CYR61 concentrations or control (without CYR61) (Fig. 2E). 

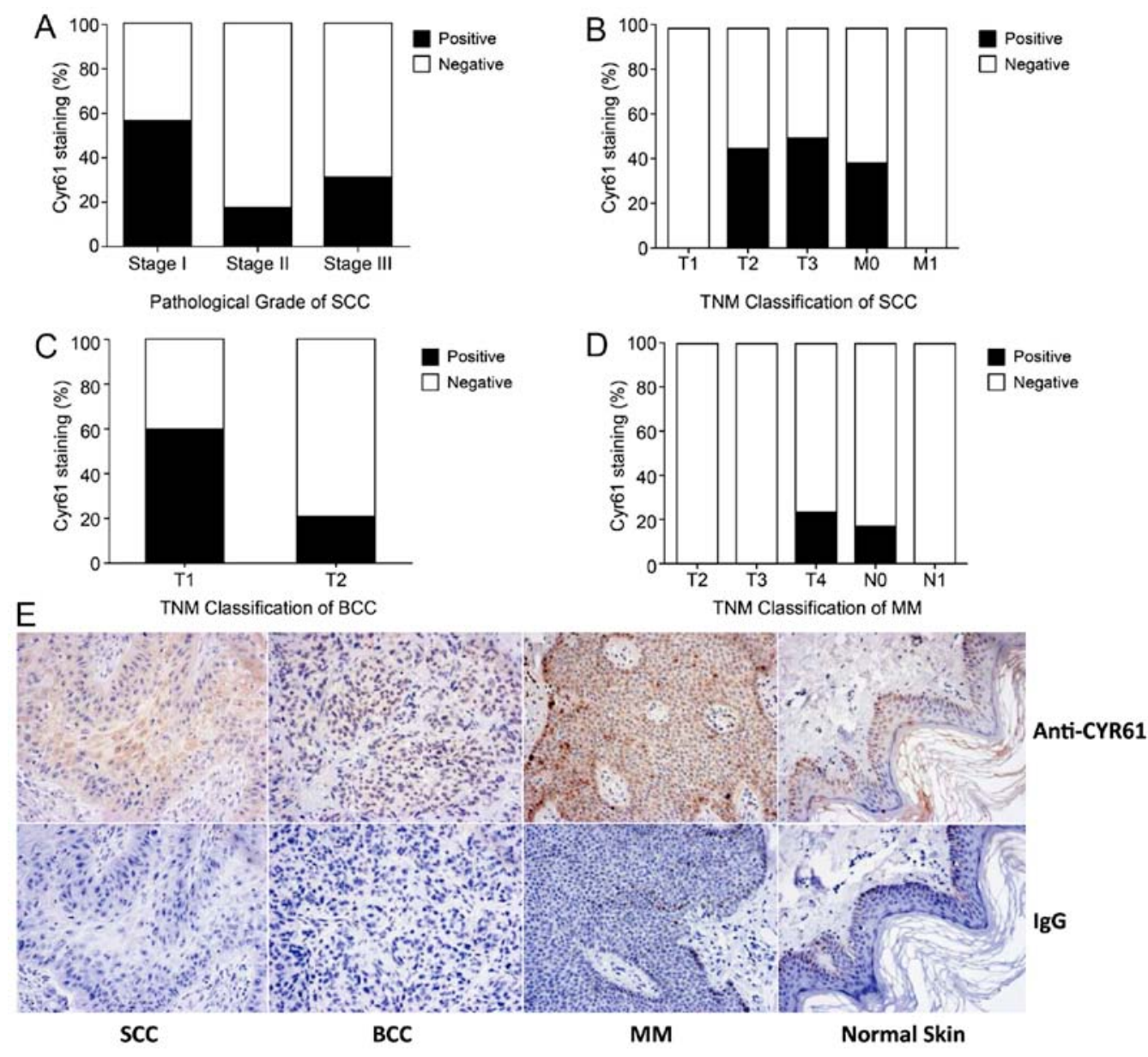

Figure 1. Cysteine-rich protein 61 (CYR61) expression in various skin samples. (A) CYR61 expression in squamous cell carcinoma (SCC) of various pathological grades. (B) CYR61 expression at various TNM stages of SCC. (C) The expression of CYR61 in basal cell carcinoma (BCC) at different TNM stages. (D) CRY61 expression in malignant melanoma (MM) at different TNM stages. (E) Immunohistochemical staining of CYR61 in tissues treated with anti-CYR61 monoclonal antibody or IgG at x200 magnification.

Anti-tumoral effect of epirubicin and IFNa on B16 cells. Epirubicin and IFN- $\alpha$ were added to B16 cells and the proliferation rate was monitored to determine their effect on cell growth. To evaluate the antitumor effect of different individual concentrations of epirubicin $(0,0.075,0.15,0.3,0.6$ and $1.2 \mu \mathrm{g} / \mathrm{ml})$ and IFN- $\alpha\left(0,10^{2}, 10^{3}\right.$ and $\left.10^{4} \mathrm{IU} / \mathrm{ml}\right)$, cells (2.0x $10^{3} /$ well) were seeded into 96 -well plates and $24 \mathrm{~h}$ later, they were incubated with various doses of drugs. Cell growth was evaluated by the MTT assay after 12, 24 and $48 \mathrm{~h}$ of treatment. As shown in Fig. 3, both epirubicin and IFN- $\alpha$ had the ability to inhibit B16 proliferation. After $12 \mathrm{~h}$ of treatment with different concentrations of drugs, there was no difference in cell growth, suggesting that cells were probably not in the proliferative stage yet. After $24 \mathrm{~h}$, the 6 different doses of epirubicin did not show a statistically significant cell growth, while $10^{4} \mathrm{IU} / \mathrm{ml} \mathrm{IFN}-\alpha$ clearly inhibited proliferation $(\mathrm{p}<0.05)$. Forty-eight hours later, both $0.075-1.2 \mu \mathrm{g} / \mathrm{ml}$ of epirubicin and $10^{3}-10^{4} \mathrm{IU} / \mathrm{ml}$ IFN- $\alpha$ strongly inhibited B16 growth, compared with other doses tested. In addition, the number of cells in the 0.3 or $0.6 \mu \mathrm{g} / \mathrm{ml}$ epirubicin treatment groups were decreased $(\mathrm{p}<0.05$ and $\mathrm{p}<0.01$, respectively) (Fig. 3A).

CYR61 and PCNA expression when B16 proliferation is inhibited. We further determined CYR61 and PCNA expression in B16 cells treated with $0.3 \mu \mathrm{g} / \mathrm{ml}$ epirubicin or $10^{3} \mathrm{IU} / \mathrm{ml}$
IFN- $\alpha$. To analyze the relationship between cell growth and CYR61 expression, we evaluated CYR61 gene expression at different time-points using quantitative real-time PCR, and CYR61 protein expression using western blot analysis.

In Fig. 4, we show that after $24 \mathrm{~h}$ of treatment, neither $0.3 \mu \mathrm{g} / \mathrm{ml}$ epirubicin nor $10^{3} \mathrm{IU} / \mathrm{ml}$ IFN- $\alpha$ inhibited B16 proliferation or promoted CYR61 expression. However, $48 \mathrm{~h}$ later, epirubicin inhibited cell growth and promoted apoptosis, while IFN- $\alpha$ had no effect (Fig. 4B). PCNA is an important indicator for proliferation and differentiation of tumor cells. As shown in Fig. $4 \mathrm{C}$, at the $24 \mathrm{~h}$ point, $0.3 \mu \mathrm{g} / \mathrm{ml}$ epirubicin inhibited PCNA expression, although the proliferative status of the cells did not change. After $48 \mathrm{~h}$, both $0.3 \mu \mathrm{g} / \mathrm{ml}$ epirubicin and $10^{3} \mathrm{IU} / \mathrm{ml} \mathrm{IFN}-\alpha$ inhibited the proliferation of B16 cells, a process accompanied by decreased PCNA expression. This suggests that epirubicin had an earlier and sharper effect than IFN- $\alpha$ on PCNA expression. Also, they probably have a different mechanism of action, since solely epirubicin inhibits proliferation and promotes apoptosis by upregulating CYR61.

\section{Discussion}

CYR61 has been reported to be overexpressed in different clinical stages of several types of tumors, such as breast cancer $(22,23)$, glioma (24), and pancreatic cancer (25). 
A Genes Genes identified as putative homologs of one another

[1] CYR61, Homo sapiens

cysteine-rich, angiogenic inducer, 61

CYR61, Pan troglodytes

cysteine-rich, angiogenic inducer, 61

[1] CYR61, Canis lupus familianis

cysteine-rich, angiogenic inducer, 61

[] CYR61, Bos taurus

giogenic inducer, 61

Cyr61, Mus musculus

cysteine rich protein 6

Cyr61, Rattus norvegicus

cysteine-rich, angiogenic inducer, 61

[9] CYR61, Gallus gallus

cysteine-rich, angiogenic inducer, 61

[3] 2gc:85866, Danio rerio

$20 \mathrm{c}: 85866$
Proteins

Proteins used in segurnce comparisons and that consener

domain architectures.

[9] $\mathrm{NP}_{381} 001545.2=$

381 aa

[] $\underset{59-513529.2}{X 99}$

[1] XP_537091.2

NP_001029512.1- $=$

[1] ${ }_{379 \mathrm{aa}}^{\mathrm{NP}}$ 034646.1 $=$

NP_-112617

$\mathrm{NP} \_0010200$
375 aa

[ $\mathrm{NP}_{-} 001$

B GENE ID: 16007 Cyr61 | cysteine rich protein 61 [Mus musculus]

Score $=665$ bits (1717), Expect $=0.0$, Method: Compositional matrix adjust.

Identities $=350 / 383$ (91\%), Positives $=360 / 383$ (93\%), Gaps $=6 / 383(1 \%)$.

Query 1 MSSRIARALALVVTLLHTRLALSTCPAACHCPLEAPKCAPGVGLVROGCGCCKVCAKOL 60.

Sbjet 1 MSSTFRTLAVA-TUHLTRLALSTCPAACHCPLEAPKCAPGVGLVRDGCGCCKVCAKQL 60 .

QUerY 61 NEOCSKTQPCDHTKGLECNFGASSTALKGICRAOSEGRPCEYNSRIYONGESFOPNCKHQ 120.

SbjCt 61 NEDCSKTOPCOHTKGLECNFGASSTALKGICRAQSEGRPCEYNSRIYQNGESFQPNCKHQ 120

Query 121 CTCIDGAVGCIPLCPQELSLPNLGCPNPRLVKVTGQCCEEWVCDEDSIKDPMEDQDGLLG 180.

Sbjet 121 CTCIDGAVGCIPICPQELSLPNLGCPNPRLVKVSGQCCEEWVCDEDSIKD LDDODDUG 180.

Query 181 KELGFDASEVEUTRNNELAVGKGSSLKRLPVFGMEPAIIYNPL-QGQKCIVQTTSWSQ 238.

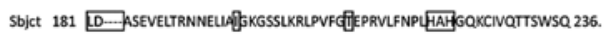

QuerY 239 CSKTCGTGISTRVTNONPECRLVKETRICEVRPCGQPVYSSLKKGKKCSKTKKSPEPVRF 298.

Sbjct 237 CSWEGGGGISTRVTNONPECRIVKETRICEVRPCGQPWVSSLKKGKKCSKTKKSPEPVRF 296.

QUETY 299 TYAGCLSVKKYRPKYCGSCVDGRCCTPQLITTVKMRFRCEOGETFSKNVMMIQSCKCNYN 358.

Sbjct 297 TYAGQSSVKKYRPKYCGSCVDGRCCTR

QUerY 359 CPHANEAAFPLYRLFNDIHKFRD 381.

Sbjet 357 CPHENEAERRIYS,FNDIHKFRD 379 .
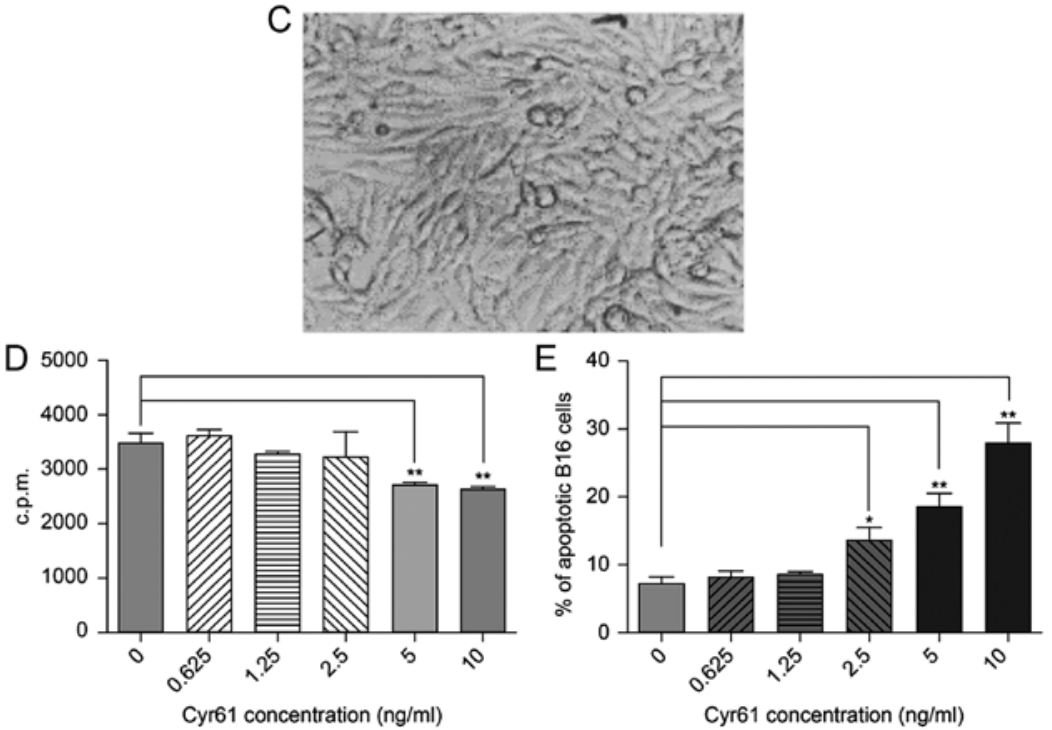

Figure 2. (A) Genes and proteins homologous to human cysteine-rich protein 61 (CYR61) determined by NCBI HomoloGene. (B) Blast comparison of human and mouse CYR61 protein sequences. First line is the human CYR61 sequence, second the mouse CYR61 sequence, and boxed are the areas different between the two sequences. (C) B16 cells at x20 magnification. (D) Relationship between CYR61 levels and B16 cell proliferation in vitro. (E) Relationship between CYR61 levels and B16 apoptosis in vitro.

However, in other cancers, such as: non-small cell lung cancer (NSCLC) (11,26), endometrial cancer, and papillary thyroid carcinoma (27-29), the levels of CYR61 were shown to be reduced. Currently, the expression profile of CYR61 in Chinese patients with malignant melanoma is unclear.

Malignant melanoma has a complex array of pathological features. During early stages, it is often misdiagnosed as hyperpigmentation or nevi, due their similarities in appearance. The incidence and exact mechanism of malignant melanoma remain unclear, and some of the etiological factors that have been implicated are malignant transformation of nevi, ultraviolet radiation, racial and genetic background, trauma, viral infection, and reduced immunity (30-33). Several studies have reported abnormal gene and protein expression in malignant melanoma, especially of the malignant melanoma growth-related factors (34-37). Tumor suppressor genes may 

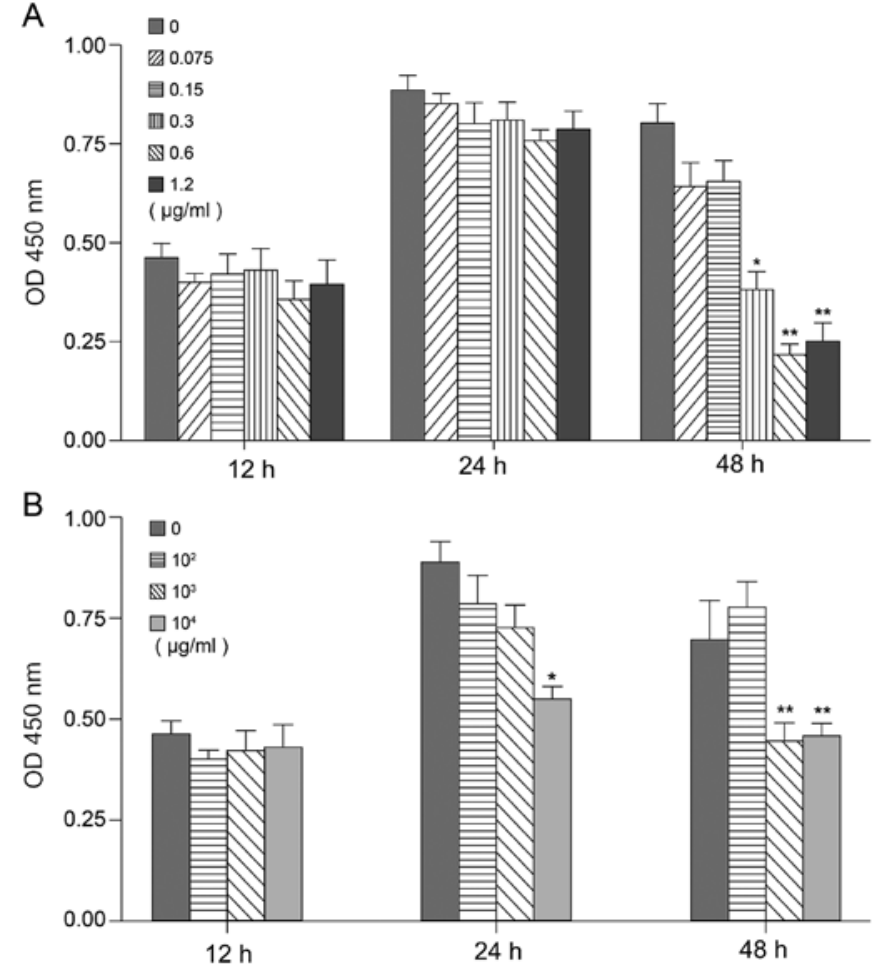

Figure 3. Cell growth after 12,24 and $48 \mathrm{~h}$ of culture in medium with various doses of epirubicin $(0,0.075,0.15,0.3,0.6$ and $1.2 \mu \mathrm{g} / \mathrm{ml})$ or IFN- $\alpha\left(0,10^{2}, 10^{3}\right.$ and $10^{4} \mathrm{IU} / \mathrm{ml}$ ). (A) After 48 -h treatment with $0.3 \mu \mathrm{g} / \mathrm{ml}$ or more epirubicin, B16 cell growth was inhibited significantly. (B) High doses $\left(10^{3}-10^{4} \mathrm{IU} / \mathrm{ml}\right)$ of IFN- $\alpha$ had an inhibiting effect on the B16 growth $\left({ }^{*} \mathrm{p}<0.05,{ }^{* *} \mathrm{p}<0.01\right)$.

also play an important role in melanoma progression and aggression.

Here, we analyzed the expression profile of CYR61 in skin samples from 78 Chinese patients with different pathologies, including three common skin tumors (BCC, SCC, and malignant melanoma), inflammatory lesions, and normal skins. Samples were placed on TMAs, balanced and normalized by age and gender. The level of CYR61 was examined by IHC and analyzed in correlation with the pathological diagnosis.

CYR61 stained positive in normal skin and skin with chronic inflammation around 80 and $75 \%$, respectively. Compared with levels found in normal skin, CRY61 was reduced in malignant melanoma and $\mathrm{BCC}$ tissues, and overexpressed in SCC tissues. Interestingly, we found no direct relationship between the CRY61 expression and the TNM stage. The percentage of CRY61-positive cells was significantly lower in malignant tumors than in normal or chronic inflammation skin. CYR61 expression was decreased in most tumor tissues, mostly in malignant melanoma. This suggests that CYR61 could become a potential therapeutic target and marker for this cancer. Thus, we used a murine malignant melanoma cell line (B16) to examine the effects of exogenous CYR61 on cell proliferation and apoptosis in vitro. Our results show that exogenous CYR61 inhibits cell growth and increases apoptosis.

In cancer therapy, proto-oncogenes are targeted to block or reduce cancer cell activities, and tumor suppressor are targeted to restore or increase their activity (38-43). CYR61 could be classified as a tumor suppressor gene, since when mutated, the inhibition of tumor growth is lost. While it seems

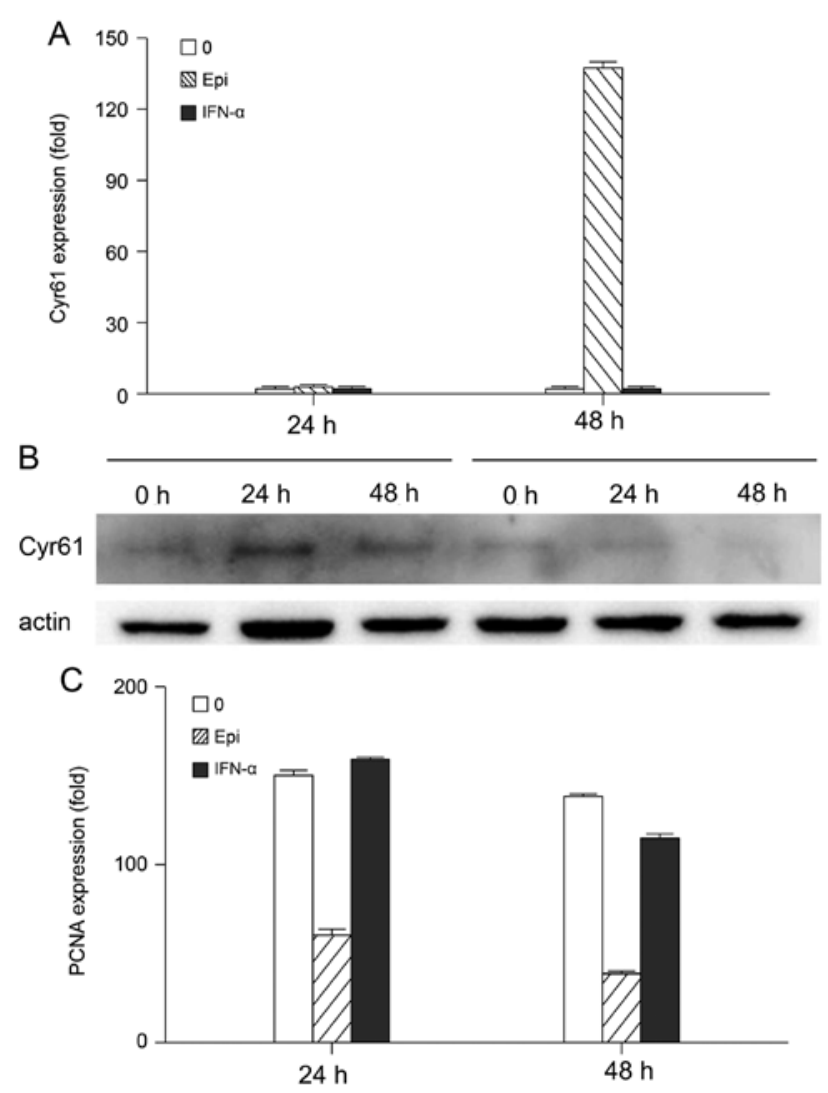

Figure 4. Effect of $0.3 \mu \mathrm{g} / \mathrm{ml}$ epirubicin or $10^{3} \mathrm{IU} / \mathrm{ml} \mathrm{IFN}-\alpha$ on CYR61 and PCNA expression in B16 cells. (A) Effect of $0.3 \mu \mathrm{g} / \mathrm{ml}$ epirubicin and $10^{3} \mathrm{IU} / \mathrm{ml}$ IFN- $\alpha$ on the CYR61 gene expression at different time-points, determined by real-time PCR. (B) Effect of $0.3 \mu \mathrm{g} / \mathrm{ml}$ epirubicin and $10^{3} \mathrm{IU} / \mathrm{ml} \mathrm{IFN}-\alpha$ on the CYR61 protein expression at different time-points, determined by western blot analysis. (C) Effects of $0.3 \mu \mathrm{g} / \mathrm{ml}$ epirubicin and $10^{3} \mathrm{IU} / \mathrm{ml} \mathrm{IFN}-\alpha$ on PCNA gene expression at different time-points.

to act similarly to p53 a tumor growth suppressor gene, its role has not been reported yet. This could be a significant finding for the treatment and outcome of malignant melanoma.

Two anti-tumoral drugs, epirubicin and IFN- $\alpha$, were used to study the B16 cell growth and apoptosis. We first focused on determining the optimal dose and time of action for IFN- $\alpha$ and epirubicin. The results showed that $0.3 \mu \mathrm{g} / \mathrm{ml}$ epirubicin or $10^{3} \mathrm{IU} / \mathrm{ml} \mathrm{IFN}-\alpha$ had negative effects on B16 cells. We also found that no cell inhibition appeared before $24 \mathrm{~h}$ of treatment, and that $48 \mathrm{~h}$ of treatment was best for suppressing growth. Based on the cell growth curve, at $12 \mathrm{~h}$ post-treatment, cells were yet to enter the proliferative phase, and at $24 \mathrm{~h}$, when proliferation reached a peak, the inhibitory effect of IFN- $\alpha$ or epirubicin began to appear. CYR61 expression increased after $48 \mathrm{~h}$ of treatment with epirubicin, but not with IFN- $\alpha$. Western blot analysis confirmed that IFN- $\alpha$ may affect B16 cell growth through a non-CYR61 pathways.

PCNA is an essential protein for eukaryotic DNA synthesis, closely related to several cell cycle regulators $(44,45)$. It expresses abnormally in a variety of malignant tumors. Therefore, PCNA can be an important indicator of cell proliferation and DNA synthesis. Previous studies confirmed that intracellular microinjection of PCNA antisense oligonucleotides or antibodies can inhibit DNA synthesis and cell cycle progression (46-50). Studies on the expression of survivin, an inhibitor of apoptosis, show that it may be associated with 
the development of choroidal melanoma. Since PCNA is directly related to survivin protein, the PCNA proliferation index increase parallels the survivin increase in choroidal melanoma. This suggests that PCNA may be an inhibitor of apoptosis during choroidal melanoma development.

Our data indicated that after $24 \mathrm{~h}$ of treatment with epirubicin, PCNA expression was inhibited, while B16 growth did not change significantly. When epirubicin and IFN- $\alpha$ inhibited B16 proliferation, CYR61 expression decreased significantly. There was an increase in apoptotic cells, consistent with the low levels of PCNA. At $48 \mathrm{~h}$, the PCNA expression was severely reduced, suggesting that epirubicin suppresses B16 cell growth, by inhibiting either survivin or another apoptosis suppressor gene. The effect of IFN- $\alpha$ on PCNA expression was minimal and discernible only after $48 \mathrm{~h}$. These results showed that both drugs inhibit B16 cell proliferation by decreasing PCNA expression. Epirubicin had an earlier and sharper effect than IFN- $\alpha$ on PCNA expression, probably due to different mechanisms of action. While epirubicin inhibited proliferation and promoted apoptosis by upregulating CYR61, IFN- $\alpha$ is likely to have a different target.

IFN- $\alpha$, a soluble glycoprotein, is produced by a variety of cells with a various anti-viral, anti-tumoral and immunomodulatory roles (51). Recent studies have shown that IFN also inhibits tumor angiogenesis (52-54). Currently, IFN type I is widely used in treatment of hematological cancers (55), follicular lymphoma (56), chronic myeloid leukemia (57), multiple myeloma (58) and solid tumors (59), AIDS related Kaposi's sarcoma (60), renal carcinoma (61), and endocrine pancreatic tumors (62). IFN I inhibits DNA synthesis and slows the mitosis rate in a selective manner, since tumor cells are 500-1,000 times more resilient than normal cells. In our study, IFN- $\alpha$ inhibited cell proliferation, but did not affect the CRY61 expression. CYR61 inhibits B16 cell proliferation and promotes apoptosis, when survivin and PCNA expression is reduced, a mechanism confirmed when using epirubicin. IFN- $\alpha$ did not inhibit cell growth by activating CYR61 and had only a slight inhibiting effect on PCNA expression.

In conclusion, in this study, we found that CYR61 expression was lower in Chinese patients with malignant melanoma compared with that of patients with other skin tumors or normal skin. CYR61 expression was also reduced in proliferative B16 cells. Using epirubicin and IFN- $\alpha$ to inhibit B16 proliferation, we also found increased CYR61 and decreased PCNA expression in arrested B16 cells. In conclusion, our study provides evidence that CYR61 may be a potential therapeutic target for malignant melanoma patients with high CYR61.

\section{Acknowledgements}

This study is supported by grants from the Department of Dermatology and Cutaneous Surgery of Shanghai Ninth People's Hospital (Affiliated to Shanghai Jiaotong University School of Medicine).

\section{References}

1. Lau LF and Nathans D: Identification of a set of genes expressed during the G0/G1 transition of cultured mouse cells. EMBO J 4 3145-3151, 1985.
2. Brigstock DR, Goldschmeding R, Katsube KI, Lam SC, Lau LF, Lyons K, Naus C, Perbal B, Riser B, Takigawa M, et al: Proposal for a unified CCN nomenclature. Mol Pathol 56: 127-128, 2003.

3. Perbal B: CCN proteins: Multifunctional signalling regulators. Lancet 363: 62-64, 2004.

4. O'Brien TP, Yang GP, Sanders L and Lau LF: Expression of cyr61, a growth factor-inducible immediate-early gene. Mol Cell Biol 10: 3569-3577, 1990.

5. Brunner A, Chinn J, Neubauer M and Purchio AF: Identification of a gene family regulated by transforming growth factor-beta. DNA Cell Biol 10: 293-300, 1991.

6. Jay P, Bergé-Lefranc JL, Marsollier C, Méjean C, Taviaux S and Berta P: The human growth factor-inducible immediate early gene, CYR61, maps to chromosome 1p. Oncogene 14: 1753-1757, 1997.

7. Martinerie C, Viegas-Pequignot E, Nguyen VC and Perbal B: Chromosomal mapping and expression of the human cyr61 gene in tumour cells from the nervous system. Mol Pathol 50: 310-316, 1997.

8. Brigstock DR: The CCN family: A new stimulus package. J Endocrinol 178: 169-175, 2003.

9. Menéndez JA, Mehmi I, Griggs DW and Lupu R: The angiogenic factor CYR61 in breast cancer: Molecular pathology and therapeutic perspectives. Endocr Relat Cancer 10: 141-152, 2003.

10. Leask A and Abraham DJ: All in the CCN family: Essential matricellular signaling modulators emerge from the bunker. J Cell Sci 119: 4803-4810, 2006.

11. Tong X, O'Kelly J, Xie D, Mori A, Lemp N, McKenna R, Miller CW and Koeffler HP: Cyr61 suppresses the growth of non-small-cell lung cancer cells via the beta-catenin-c-myc-p53 pathway. Oncogene 23: 4847-4855, 2004.

12. Kim SY, Hahn HG, Nam KD, Park KC, Yun HY, Baek KJ, Kwon NS and Kim DS: A derivative of 2-aminothiazole inhibits melanogenesis in B16 mouse melanoma cells via glycogen synthase kinase $3 \beta$ phosphorylation. J Pharm Pharmacol 63: 1031-1036, 2011.

13. Klebanoff CA, Gattinoni L, Palmer DC, Muranski P, Ji Y, Hinrichs CS, Borman ZA, Kerkar SP, Scott CD, Finkelstein SE, et al: Determinants of successful CD8 ${ }^{+} \mathrm{T}$-cell adoptive immunotherapy for large established tumors in mice. Clin Cancer Res 17: 5343-5352, 2011.

14. Xiao H, Peng Y, Hong Y, Liu Y, Guo ZS, Bartlett DL, Fu N and He Y: Lentivector prime and vaccinia virus vector boost generate high-quality CD8 memory $\mathrm{T}$ cells and prevent autochthonous mouse melanoma. J Immunol 187: 1788-1796, 2011.

15. Babic AM, Kireeva ML, Kolesnikova TV and Lau LF: CYR61, a product of a growth factor-inducible immediate early gene, promotes angiogenesis and tumor growth. Proc Natl Acad Sci USA 95: 6355-6360, 1998.

16. Kunz M, MoellerS, KoczanD, Lorenz P, WengerRH, GlockerMO, Thiesen HJ, Gross G and Ibrahim SM: Mechanisms of hypoxic gene regulation of angiogenesis factor Cyr61 in melanoma cells. J Biol Chem 278: 45651-45660, 2003.

17. Dobroff AS, Wang H, Melnikova VO, Villares GJ, Zigler M, Huang L and Bar-Eli M: Silencing cAMP-response element-binding protein (CREB) identifies CYR61 as a tumor suppressor gene in melanoma. J Biol Chem 284: 26194-26206, 2009.

18. Carmichael J, DeGraff WG, Gazdar AF, Minna JD and Mitchell JB: Evaluation of a tetrazolium-based semiautomated colorimetric assay: Assessment of radiosensitivity. Cancer Res 47: 943-946, 1987.

19. Alley MC, Scudiero DA, Monks A, Hursey ML, Czerwinski MJ, Fine DL, Abbott BJ, Mayo JG, Shoemaker RH and Boyd MR: Feasibility of drug screening with panels of human tumor cell lines using a microculture tetrazolium assay. Cancer Res 48: 589-601, 1988.

20. Zhang Q, Wu J, Cao Q, Xiao L, Wang L, He D, Ouyang G, Lin J, Shen B, Shi Y, et al: A critical role of Cyr61 in interleukin-17-dependent proliferation of fibroblast-like synoviocytes in rheumatoid arthritis. Arthritis Rheum 60: 3602-3612, 2009.

21. Sun M, Ma F, Zeng X, Liu Q, Zhao XL, Wu FX, Wu GP, Zhang ZF, $\mathrm{Gu} \mathrm{B}$, Zhao YF, et al: Triphalangeal thumb-polysyndactyly syndrome and syndactyly type IV are caused by genomic duplications involving the long range, limb-specific SHH enhancer. J Med Genet 45: 589-595, 2008.

22. Lin MT, Chang CC, Chen ST, Chang HL, Su JL, Chau YP and Kuo ML: Cyr61 expression confers resistance to apoptosis in breast cancer MCF-7 cells by a mechanism of NF-kappaB-dependent XIAP up-regulation. J Biol Chem 279: 24015-24023, 2004. 
23. Menendez JA, Vellon L, Mehmi I, Teng PK, Griggs DW and Lupu R: A novel CYR61-triggered 'CYR61-alphavbeta3 integrin loop' regulates breast cancer cell survival and chemosensitivity through activation of ERK1/ERK2 MAPK signaling pathway. Oncogene 24: 761-779, 2005.

24. Xie D, Yin D, Wang HJ, Liu GT, Elashoff R, Black K and Koeffler HP: Levels of expression of CYR61 and CTGF are prognostic for tumor progression and survival of individuals with gliomas. Clin Cancer Res 10: 2072-2081, 2004.

25. Holloway SE, Beck AW, Girard L, Jaber MR, Barnett CC Jr, Brekken RA and Fleming JB: Increased expression of Cyr61 (CCN1) identified in peritoneal metastases from human pancreatic cancer. J Am Coll Surg 200: 371-377, 2005.

26. Tong X, Xie D, O'Kelly J, Miller CW, Muller-Tidow C and Koeffler HP: Cyr61, a member of CCN family, is a tumor suppressor in non-small cell lung cancer. J Biol Chem 276 : 47709-47714, 2001.

27. Sampath D,Zhu Y,WinnekerRCandZhang Z: Aberrantexpression of Cyr61, a member of the CCN (CTGF/Cyr61/Cef10/NOVH) family, and dysregulation by 17 beta-estradiol and basic fibroblast growth factor in human uterine leiomyomas. J Clin Endocrinol Metab 86: 1707-1715, 2001

28. Wasenius VM, Hemmer S, Kettunen E, Knuutila S, Franssila K and Joensuu $\mathrm{H}$ : Hepatocyte growth factor receptor, matrix metalloproteinase-11, tissue inhibitor of metalloproteinase-1, and fibronectin are up-regulated in papillary thyroid carcinoma: A cDNA and tissue microarray study. Clin Cancer Res 9: 68-75, 2003

29. Chien W, Kumagai T, Miller CW, Desmond JC, Frank JM, Said JW and Koeffler HP: Cyr61 suppresses growth of human endometrial cancer cells. J Biol Chem 279: 53087-53096, 2004.

30. Dika E, Fanti PA, Vaccari S, Patrizi A and Maibach HI: Causal relationship between exposure to chemicals and malignant melanoma? A review and study proposal. Rev Environ Health 25 255-259, 2010.

31. Kong Y, Kumar SM and Xu X: Molecular pathogenesis of sporadic melanoma and melanoma-initiating cells. Arch Patho Lab Med 134: 1740-1749, 2010.

32. Mihić LL, Bulat V, Situm M, Krolo I and Seserko A: The role of apoptosis in the pathogenesis of malignant melanoma. Coll Antropol 34 (Suppl 2): 303-306, 2010.

33. Khalid U, Saleem T, Imam AM and Khan MR: Pathogenesis, diagnosis and management of primary melanoma of the colon. World J Surg Oncol 9: 14, 2011.

34. Gruber F, Kastelan M, Brajac I, Saftić M, Peharda V, Cabrijan L, Stanić Zgombić Z and Simonić E: Molecular and genetic mechanisms in melanoma. Coll Antropol 32 (Suppl 2): 147-152, 2008

35. Ibrahim N and Haluska FG: Molecular pathogenesis of cutaneous melanocytic neoplasms. Annu Rev Pathol 4: 551-579, 2009.

36. Russo AE, Torrisi E, Bevelacqua Y, Perrotta R, Libra M, McCubrey JA, Spandidos DA, Stivala F and Malaponte G: Melanoma: Molecular pathogenesis and emerging target therapies (Review). Int J Oncol 34: 1481-1489, 2009.

37. Ugurel S, Utikal J and Becker JC: Tumor biomarkers in melanoma. Cancer Control 16: 219-224, 2009.

38. Chandeck C and Mooi WJ: Oncogene-induced cellular senescence. Adv Anat Pathol 17: 42-48, 2010.

39. Parsons BL, Myers MB, Meng F, Wang Y and McKinzie PB: Oncomutations as biomarkers of cancer risk. Environ Mol Mutagen 51: 836-850, 2010.

40. Adhikari AS and Iwakuma T: Mutant p53 gain of oncogenic function: In vivo evidence, mechanism of action and its clinical implications. Fukuoka Igaku Zasshi 100: 217-228, 2009.

41. Bar J, Moskovits N and Oren M: Involvement of stromal p53 in tumor-stroma interactions. Semin Cell Dev Biol 21: 47-54, 2010.

42. Lane D and Levine A: p53 Research: The past thirty years and the next thirty years. Cold Spring Harb Perspect Biol 2 a000893, 2010

43. Solomon H, Brosh R, Buganim Y and Rotter V: Inactivation of the p53 tumor suppressor gene and activation of the Ras oncogene: Cooperative events in tumorigenesis. Discov Med 9: 448-454, 2010.
44. Dervan PA, Magee HM, Buckley C and Carney DN: Proliferating cell nuclear antigen counts in formalin-fixed paraffin-embedded tissue correlate with Ki-67 in fresh tissue. Am J Clin Pathol 97 (Suppl 1): S21-S28, 1992.

45. Bolton WE, Mikulka WR, Healy CG, Schmittling RJ and Kenyon NS: Expression of proliferation associated antigens in the cell cycle of synchronized mammalian cells. Cytometry 13: 117-126, 1992.

46. Nakano H, Namatame K, Suzuki T, Takahashi H, Sakai H, Nakamura T and Kumada K: Histopathological response to preoperative chemotherapy including 5-fluorouracil additionally assessed by immunocytochemical and pharmacologic parameters in patients with advanced gastric cancer. Surg Today 26: 482-488, 1996.

47. Hiraga Y, Tanaka S, Haruma K, Yoshihara M, Sumii K, Kajiyama G, Shimamoto F and Kohno N: Immunoreactive MUC1 expression at the deepest invasive portion correlates with prognosis of colorectal cancer. Oncology 55: 307-319, 1998.

48. Kunihiro M, Tanaka S, Haruma K, Yoshihara M, Sumii K, Kajiyama $G$ and Shimamoto F: Combined expression of HLA-DR antigen and proliferating cell nuclear antigen correlate with colorectal cancer prognosis. Oncology 55: 326-333, 1998.

49. Jia X and Han C: Biomarkers in the studies on chemoprevention of colorectal cancer. Wei Sheng Yan Jiu 29: 109-111, 2000 (In Chinese)

50. Reszeć J, Kańczuga-Koda L, Sulkowska M, Koda M, Cylwik J, Barwijuk-Machała M and Sulkowski S: An evaluation of Ki-67 and PCNA expression in conjunctival and eyelid tumours. Folia Morphol (Warsz) 63: 95-98, 2004.

51. Meyer O: Interferons and autoimmune disorders. Joint Bone Spine 76: 464-473, 2009.

52. Heng DY and Bukowski RM: Anti-angiogenic targets in the treatment of advanced renal cell carcinoma. Curr Cancer Drug Targets 8: 676-682, 2008.

53. Agarwala SS and Case S: Everolimus (RAD001) in the treatment of advanced renal cell carcinoma: A review. Oncologist 15: 236-245, 2010.

54. Ather MH, Masood N and Siddiqui T: Current management of advanced and metastatic renal cell carcinoma. Urol J 7: 1-9, 2010.

55. Ramakrishna R and Manoharan A: Sustained long-term remissions with weekly interferon maintenance therapy in hairy cell leukemia. Asia Pac J Clin Oncol 6: 210-212, 2010.

56. Baldo P, Rupolo M, Compagnoni A, Lazzarini R, Bearz A, Cannizzaro R, Spazzapan S, Truccolo I and Moja L: Interferon-alpha for maintenance of follicular lymphoma. Cochrane Database Syst Rev: CD004629, 2010.

57. Burchert A and Neubauer A: Interferon alpha and T-cell responses in chronic myeloid leukemia. Leuk Lymphoma 46: $167-175,2005$.

58. Khoo TL, Vangsted AJ, Joshua D and Gibson J: Interferon-alpha in the treatment of multiple myeloma. Curr Drug Targets 12: 437-446, 2011.

59. Garbe C, Eigentler TK, Keilholz U, Hauschild A and Kirkwood JM: Systematic review of medical treatment in melanoma: Current status and future prospects. Oncologist 16: 5-24, 2011.

60. Aversa SM, Cattelan AM, Salvagno L, Crivellari G, Banna G, Trevenzoli M, Chiarion-Sileni V and Monfardini S: Treatments of AIDS-related Kaposi's sarcoma. Crit Rev Oncol Hematol 53: 253-265, 2005

61. Chowdhury S, Larkin JM and Gore ME: Recent advances in the treatment of renal cell carcinoma and the role of targeted therapies. Eur J Cancer 44: 2152-2161, 2008.

62. Massironi S, Sciola V,Peracchi M,CiafardiniC, Spampatti MP and Conte D: Neuroendocrine tumors of the gastro-entero-pancreatic system. World J Gastroenterol 14: 5377-5384, 2008. 